\title{
Simulation of Groundwater Flow and the Hydrological Balance of the Tecocomulco Lagoon, Central México
}

\author{
Rafael Huizar-Alvarez ${ }^{*}$, Guillermo Hernández-García $^{2}$ and José Joel Carrillo-Rivera ${ }^{3}$ \\ ${ }^{1}$ Instituto de Geología, ${ }^{2}$ Instituto de Geofísica, ${ }^{3}$ Instituto de Geografía. Universidad Nacional Autónoma de México, \\ Ciudad Universitaria, Coyoacán, 04510, D.F., México
}

\begin{abstract}
Groundwater flow simulation in the Tecocomulco sub-basin confirms its local discharge nature. This upward flow supplies boreholes, dug-wells and the Tecocomulco lagoon. From a regional perspective, this sub-basin recharges the neighbouring Apan and Singuilucan sub-basins, and the Mexico basin. Despite the fact that the Tecocomulco plain is a local discharge zone, unplanned groundwater withdrawal and land-use changes have led to the drying of the lagoon. Landuse change causes an increase in surface runoff inducing an estimated 35\% decrease in recharge. Modelling reproduced initial conditions and observed drawdown levels from where the hydraulic and hydrological functioning of the Tecocomulco lagoon was proposed. Modelling assisted in verifying effects caused by current groundwater withdrawal. Time dependant desiccation of the lagoon was reproduced independently of borehole location. Maximum allowable simulated additional increase in groundwater withdrawal was $0.1 \mathrm{~m}^{3} \mathrm{~s}^{-1}$. Strict surveillance of land-use and reforestation practices in the sub-basin is needed to avoid the disappearance of the lagoon.
\end{abstract}

Keywords: Mexico, lagoon, recharge zone, wetland, aquifer, land-use.

\section{INTRODUCTION}

For the last 60 years, the available water supply infrastructure of the Mexico Basin, in particular that of Mexico City, has not grown at the rate required by urban centres. The constant annual population growth of $4 \%$ means that the deficit in the water that is delivered will be even greater. Moreover, groundwater usage policy implemented by the authorities in the basin has produced environmental effects such as: (i) water-table decline, (ii) extinction of springs, (iii) subsidence of the land surface, (iv) groundwater contamination induced and captured by withdrawal boreholes, $(v)$ disappearance of phreatophytes caused by excessive withdrawal and (vi) delivery of lower quality water. To cope with the water supply needs of the population, in some municipalities, the authorities have been importing surface and groundwater from neighboring sub-basins. This is the case in Mexico City and other major urban centres in the sub-basin like Pachuca, Sahagún, and Singuilucan. In these cases, importing water has proved not to be the best solution, as it has caused undesirable alterations in the hydrogeologic dynamics of those sub-basins.

The availability of water sources is a constant political problem, and requires the correction of groundwater source management policy implemented within the Basin of Mexico. The Tecocomulco sub-basin, which is located in the northeast of the Mexico Basin (Fig. 1) has the last of the natural lagoons that once featured in the Basin of Mexico (Apan, Chalco, Tecocomulco, Tenochtitlan, Texcoco, Xaltocan and Zumpango [1]). In this lagoon, aquatic and terrestrial fauna still form an ecosystem, representing a great variety of

*Address correspondence to this author at the Instituto de Geología, Universidad Nacional Autónoma de México. Ciudad Universitaria, Coyoacán, 04510, D.F., México; E-mail: huizar@servidor.unam.mx wildlife, some of which is endemic to this region. There are thousands of birds, some of which are resident and others migratory $[2,3]$ and which are part of the food-chain of some ecosystems in the region, and have become a tourist attraction. The Tecocomulco lagoon is reported $[2,4]$ to constitute the last ecological site where 36 species of aquatic plants survive from the now historical lagoons of preHispanic times. Land-use in this sub-basin (e.g., deforestation, inappropriate land cultivation practices) has altered the landscape, and is giving rise to serious environmental problems relating to the progressive extinction of the lagoon, due to: $(i)$ the direct use of its surface water for irrigation, (ii) the increased withdrawal of groundwater, and (iii) the large amount of sediment that it receives as a consequence of soil erosion, affecting the whole associated sub-basin, but mainly in the south, east and north, where the loss of the soil coverage is very severe. The eroded and transported particles are deposited into the lagoon, filling it up and increasing the flooding zone. In addition, the water surface exposed to evaporation has increased. The related loss of vegetation cover leads to an increase in surface runoff and a corresponding decrease in groundwater recharge, which in most cases is causing changes in the ecosystems and hydrological functioning of the sub-basin. The Tecocomulco sub-basin is a notable example [5]. In this sub-basin there are no hydrometric stations to register hydrologic data, which are so important in the analysis of the environmental problems involved in this study. For this reason, it was necessary to apply semi-empirical methods to evaluate surface runoff.

At present, this sub-basin provides some $20,000 \mathrm{~m}^{3} \mathrm{day}^{-1}$ of groundwater by means of boreholes for urban centres in neighbouring sub-basins, as well as for local usage. In regard to the disappearance of the lake and related impacts, this study focuses on: ( $i$ ) characterization of groundwater flow 


\section{BASIN OF MEXICO}

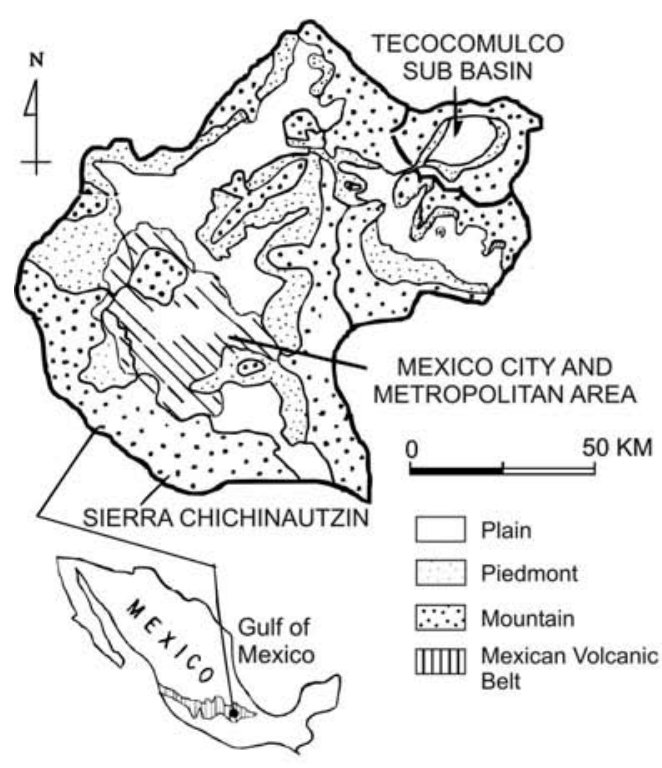

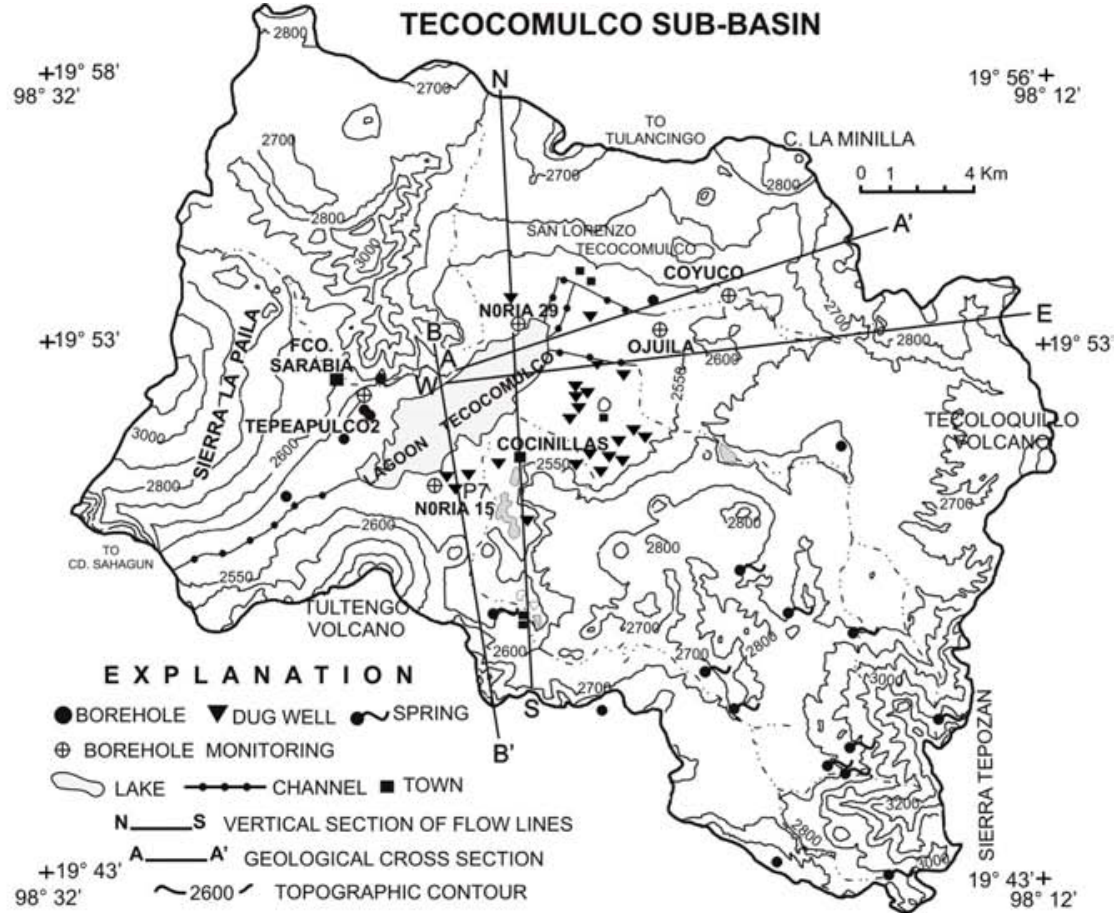

Fig. (1). Location of the study area in the Mexico Basin, showing the boreholes, dug-wells, springs, geological and vertical flow crosssections.

systems of the Tecocomulco sub-basin and their relationship with neighbouring sub-basins, (ii) assessment and forecasting of the effects of groundwater withdrawal on the lagoon and (iii) estimation of changes in groundwater recharge due to changes in land use.

\section{The Study Area}

The study area has a surface of $570 \mathrm{~km}^{2}$ and it has a volcanic relief comprising mountains of different heights, lengths and forms (Fig. 1), such as Sierra El Tepozan and La Paila, with a rough relief reaching 3,300 and $3,100 \mathrm{~m}$ a.s.l., respectively. The lower portion of the landscape corresponds to the plain of Tecocomulco, at 2,550 $\mathrm{m}$ a.s.l., surrounded by a series of volcanic mountains. The study area corresponds to a closed-surface sub-basin. The plain of the sub-basin hosts the remains of the Tecocomulco lagoon. The mean annual precipitation, temperature and evapotranspiration are $779 \mathrm{~mm}, 13.5^{\circ} \mathrm{C}$ and $550 \mathrm{~mm}$, respectively.

\section{GEOLOGIC AND HYDROGEOLOGIC MODEL}

From a structural geology point of view, the area was formerly interpreted as a NE-SW graben structure [6, 7]. Recently, it has been established $[8,9]$ that it is a half-graben delimited by NE-SW and NW-SE lineaments. The NE-SW lineament delimiting the half-graben can be projected up to the Nevada, Pachuca and Tolcayuca ranges, pointing to the existence of regional structures (Fig. 2).

The sedimentary and volcanic stratigraphic column is considered to rest on a granitic intrusive of pre-Cretaceous age.

The graben fill may be described from the youngest to the oldest unit, as follows:

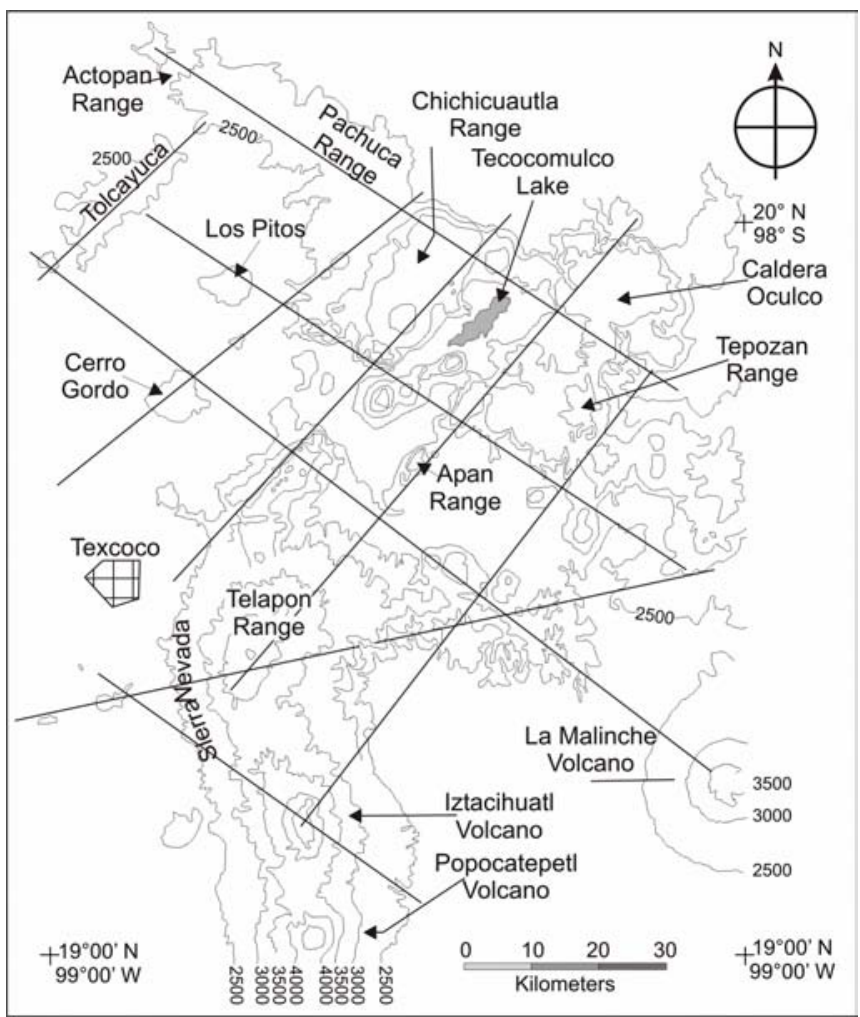

Fig. (2). Topographical context of the study area. Inferred tectonic lineaments are indicated, modified from Campos-Enríquez et al., (2003).

(i) A layer of recent clastic materials (Qal) comprising conglomerate, sand, silt and clay, interlayered with lava flows toward the periphery and centre of the 
plain. This sequence has a mean thickness of up to $600 \mathrm{~m}$, and it is defined as a mixed lithology aquifer unit with granular and fissured strata [5]. The first 90 $\mathrm{m}$ sequence of the upper and central portion of the plain corresponds to lacustrine deposits Qla (Fig. 3); this sequence constitutes an aquitard. The hydraulic conductivity $(\mathrm{K})$ of granular material and clay lenses is $10^{-3}-10^{-4} \mathrm{~m} \mathrm{~s}^{-1}$ and $10^{-8} \mathrm{~m} \mathrm{~s}^{-1}$, respectively [10]; whereas the fissured rock has a $\mathrm{K}$ value of between 2 $\times 10^{-2}$ and $1 \times 10^{-1} \mathrm{~m} \mathrm{~s}^{-1}$ [5]. These aquifer units provide the water $\left(0.612 \mathrm{~m}^{3} \mathrm{~s}^{-1}\right)$ for human consumption that is being extracted through 10 boreholes and 92 dug-wells.

(ii) A thick layer of volcanic rocks corresponds to the Quaternary, including clastic and pyroclastic material. The basaltic and basaltic-andesitic lava flows are occasionally interbedded with volcanic breccias and pyroclastic material (Figs. 3, 4). The Quaternary material has been grouped in the following units: Acoculco and Tecoloquillo Tuff (Qt), and Apan basalt (Qb) [8, 11]. The clastic and volcanic rocks have a combined thickness of between 300 and 1,600 m.

(iii) Tertiary volcanism gave rise to important volumes of fractured rhyolite and andesite flows covering up to $40 \%$ of the study area. The oldest rock units correspond to the rhyolite at the base of the igneous sequence; at the eastern and southern locations they are covered by andesitic flows. In these sectors the outcrop of rhyolitic flows are sometimes interbedded with ignimbrites. These units are covered by pyroclastic deposits of pumice, glass, lapilli and tuff. Individually, each lithology has a variable thickness, but overall they have a mean thickness of 1, $200 \mathrm{~m}$. In the northern sector, rhyolitic and andesitic rocks are covered by basaltic lava flows. The Tertiary rocks in chronological order of origin have been grouped as follows, according to their lithology: El Peñón Andesite (Tmovp), Chignahuapan Rhyolite (Tpch) [11] the Acoculco Series (Tpva) [12], and the Apan Unit (Tma). Their age ranges from Miocene to Pliocene [8], and they underlie Quaternary rocks. This volcanic sequence constitutes a fissured aquifer unit, whose hydraulic conductivity is $1.4 \times 10^{-3} \mathrm{~m} \mathrm{~s}^{-1}[5,13]$. On the plain, this volcanic aquifer unit has a hydraulic connection with the overlying mixed lithology aquifer unit.

(iv) Underlying the volcano-clastic rocks there is a metamorphosed limestone (Ks) that was identified by drilling at a depth of 800 to $1,660 \mathrm{~m}$ in Acoculco I borehole located some $5 \mathrm{~km}$ to the NE of the Tecocomulco sub-basin [14]. Based on geophysical work (gravity and magnetometric data) [9] the presence of such limestone was inferred, with variable topography, and a depth of 500-2,000 m.a.s.l. The correlation of these geophysical data with those provided by the lithological Acoculco drilling is shown in a conceptual model of the study area as depicted in Figs. $(\mathbf{3}, \mathbf{4})$, where a mean thickness of limestone from
500-1,000 m can be observed (Fig. 4). These rocks constitute a fissured aquifer unit; the hydraulic properties of these rocks were inferred from heat flow computation in limestone cuts at the Acoculco I borehole [14], and from available pumping tests data collected outside of Tecocomulco sub-basin, such as from Chignahuapan (located in the state of Puebla) approximately $20 \mathrm{~km}$ beyond its southern boundary [15]. The pumping tests incorporated the Tamaulipas Formation where hydraulic conductivity varies between $10^{-4}$ and $10^{-5} \mathrm{~m} \mathrm{~s}^{-1}$.

(v) Finally, $300 \mathrm{~m}$ of microgranitic rock has been identified at a depth of 1,660 $\mathrm{m}$ at the Acoculco I borehole [14], and it is inferred that this rock is possibly located at a depth of 2,000 $\mathrm{m}$ in the study area [9]. This rock unit is considered to be the hydrogeologic basement of the aquifer units described above.

The surface topographic relief and elevation delimiting the Tecocomulco sub-basin constitutes a recharge zone for the study area, as well as for the neighbouring Apan, Tulancingo, and Sahagún sub-basins, while the plain corresponds to a zone of local discharge characterised mainly by springs and a shallow potentiometric surface. The topographic relief and particularly high elevation (up to 3,000 m.a.s.1.), lithological nature of the Tecocomulco sub-basin, as well as the Apan sub-basin to the south and Singuilucan sub-basin to the north, possess features that imply regional recharge potential for the areas of Mexico City, Pachuca, Tulancingo and Zumpango [5].

These aquifer units have regional coverage and are part of the Trans-Mexican Volcanic Belt, and therefore from a regional perspective these units belong to a regional aquifer. The hydraulic characteristics of the aquifer units and their regional coverage provide evidence suggesting hydraulic communication with the neighbouring surface sub-basins through fractures and the inter-granular characteristics of the units, specifically with Sahagún city to the west and the Tenancingo Township to the northeast and with the Apan sub-basin to the south [7,9]. Clastic, volcanic and limestone units constitute the half-graben fill with an estimated average variable thickness of $1,300 \mathrm{~m}$ in the central part of the structure (Fig. 4).

\section{METHODS}

The territories affected by intense soil erosion, and cultivated fields located in high and low sloped terrain, are those where surface runoff increased due to the loss of vegetation cover. In addition, a decrease in infiltration has also been deduced [16]. The cartography of this territory was based on aerial photographs, and verified in the field (Fig. 5). Precipitation was calculated with precipitation distribution and [17] methods. An estimate of the value of regional evapotranspiration was calculated using the formulae proposed by [1820]. Surface runoff was estimated using the flooding coefficient according to the Soil Conservation Service method [21]. Calculated values are considered to be approximately $6,000 \mathrm{~m}^{3} /$ year, yet the degree of uncertainty is difficult to establish as there are no gauging stations in the area or in its 


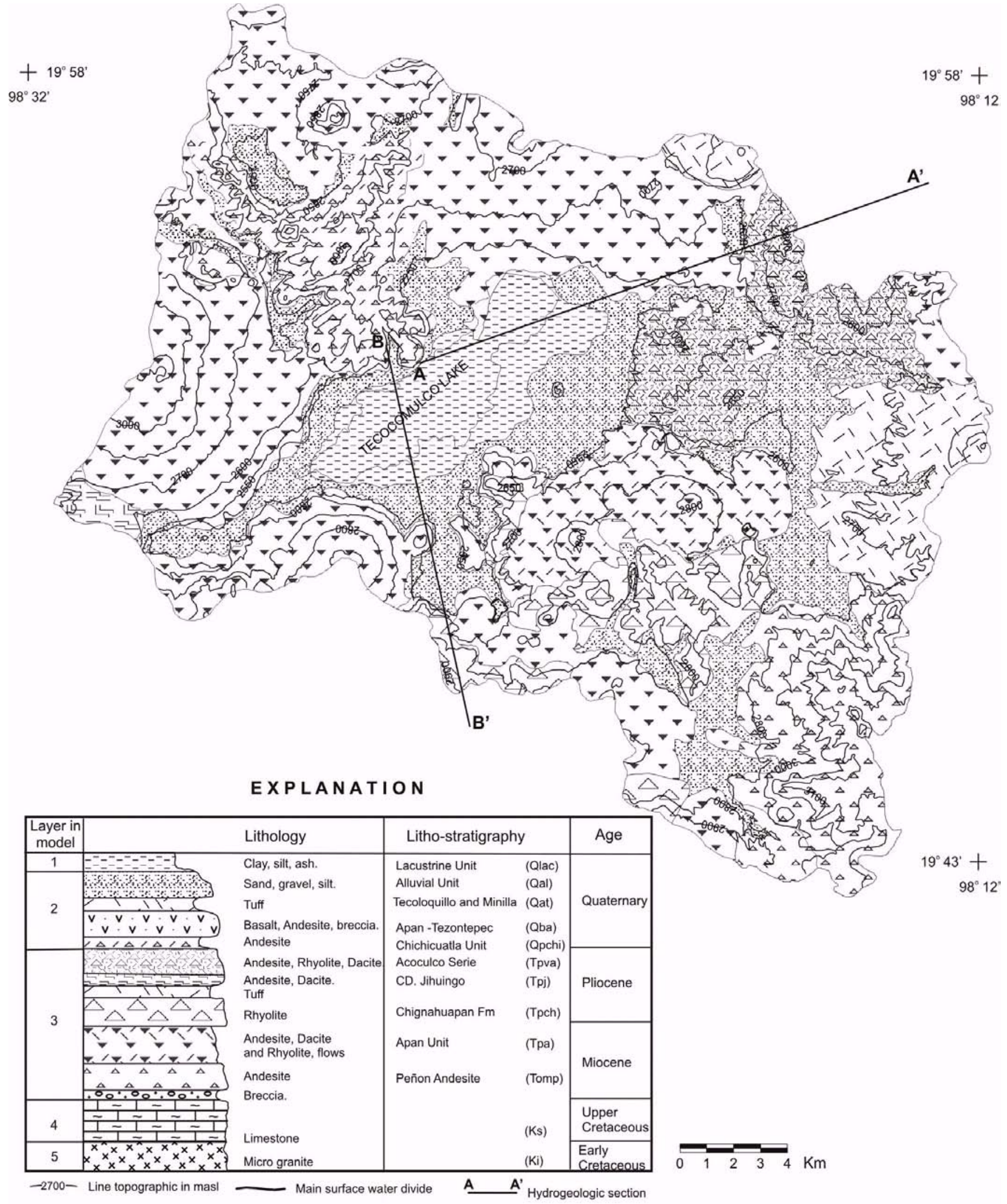

Fig. (3). Geological framework of the Tecocomulco sub-basin.

immediate vicinity. Measurements of water-table elevation (in two boreholes with a depth of up to $90 \mathrm{~m}$ ) from 1980 to
2000 were used for calibration purposes, and two dug-wells at a depth of $11 \mathrm{~m}$ also assisted in this procedure (Fig. 1). 
Groundwater discharge takes place through withdrawal by boreholes and dug-wells, as well as by spring flow. The USGS numerical model Modflow [22], was used to assess the reliability of above described hydrogeological model and to simulate groundwater flow. The 2-D graphic visualization was obtained with the Visual Modflow graphic interface (v.2.8.1) (Waterloo Hydrologic Inc.). Initial computations from the numerical model were used to calibrate the conceptual hydrogeological model in which the prevailing stratigraphy, groundwater sources, and hydrogeological properties have been incorporated. This model is in accordance with hydrogeological conceptual model proposed by $[5,9]$. The calibration of the boundary conditions and field values of $\mathrm{K}$, $\mathrm{S}$ and the potentiometric surface (Table 1; Figs. 6a, b) allowed a first attempt at obtaining the groundwater flow systems distribution in this area. The calibration procedure reproduced the potentiometric surface as obtained from field measurements. The lateral groundwater flow was estimated together with the response to different values of recharge. Finally, the simulation of the groundwater flow was carried out according to different scenarios to define its local behaviour, and the possible effects of groundwater withdrawal in the Tecocomulco lagoon.

One particular scenario was considered so as to obtain observed field potentiometric values to achieve initial conditions: the variation of recharge due to the effect that the loss of soil produces in several sectors of the sub-basin, whereby an increase in soil erosion of $0.09 \%$ [23] corresponds to a decrease in $35 \%$ of recharge. Therefore, if there is no soil erosion recharge would increase by $35 \%$ with a rise in the potentiometric values (not observed in actual field conditions). Values used in the model were obtained from the hydrological balance equation, in which $\mathrm{P}=\mathrm{Et}+\mathrm{S}+1$; where $\mathrm{P}$ = rainfall, $\mathrm{Et}=$ evapotranspiration, $\mathrm{S}=$ suface runoff, $\mathrm{I}=$ infiltration. The results are presented in Table 2 . Model conditions thus obtained were used to simulate and compare the effect of groundwater withdrawal by boreholes with the decrease of the potentiometric surface in the vicinity of the Tecocomulco lagoon.

\section{CONCEPTUAL AND NUMERICAL MODEL}

\section{Hydraulic Characteristics of Stratigraphic Strata}

The boundaries of the topographic surface included in the model are the lateral limits of the natural hydrologic system corresponding to the Tecocomulco sub-basin (Fig. 1). The lava flows that constitute the relief of the study area are interlayered with pyroclastic and clastic materials.

The conceptual model of the study area as indicated in the representative sections ( $\mathrm{A}-\mathrm{A}^{\prime}$ and $\mathrm{B}-\mathrm{B}^{\prime}$ in Fig. 4), suggests that the modelled domain is part of a regional aquifer formed of fractured and granular strata. This figure also shows the lithologic units found that are represented by eight strata. The structure and thicknesses of the three shallowest strata are known in detail through data from boreholes drilled through the aquitard and the upper part of the aquifer. The thicknesses of strata located beyond a depth of $400 \mathrm{~m}$ were established through borehole data and extrapolation with gravimetric, magnetometric, and geoelectric surveys [5, 9], as well as through lithology data from the $2,000 \mathrm{~m}$ deep Acoculco-I borehole. In the plain, the most superficial strata (clay and silt) constituted a confining $90 \mathrm{~m}$ thick layer, while the remaining underlying strata are under water-table conditions.

Regarding the hydraulic connection that exists among these materials, it is possible to group the volcanic rocks and the Quaternary granular materials into five separate hydrostratigraphic units, which were considered as five layers for the purposes of numerical simulation and are represented as sections $\mathrm{A}-\mathrm{A}^{`}$ and $\mathrm{B}-\mathrm{B}^{`}$ (Fig. 4).

The thickness and spatial distribution of these materials were considered to be almost constant within the model domain.

The values assigned to the effective porosity, elevation of the water level, hydraulic conductivity, and storativity $\left(\eta_{\mathrm{e}}, \mathrm{h}\right.$, $\mathrm{K}, \mathrm{S}$ ), respectively were obtained from pumping test (see Table 1) data [10] and assigned to layers 1,2 and 3. The modelled system is assumed to be isothermal. Obtained data values were consistent with the lithology from available boreholes.

The hydraulic conductivity assigned to each cell at the interior of the model was carried out in two steps: (i) based on available information originally assigned to each type of lithological material; (ii) values were further adjusted during extrapolation procedure incorporating structural features, as suggested by geological structure. Figs. (6a, b) show the distribution of the horizontal hydraulic conductivity assigned to layers I and II, respectively. It can be observed that the hydraulic conductivity value for the Quaternary lithology is almost one order of magnitude higher than in that of the Tertiary rocks. This difference of magnitude is explained by the Tertiary rocks, besides being covered by Quaternary rocks, being made up of andesitic and rhyolitic fractured lava, whereas the Quaternary rocks are volcanic breccia and fractured basaltic lava flows which are more fractured than the Tertiary rocks. This difference of one order of magnitude was also confirmed by the hydraulic response of the applied model.

Based on their lithologic and hydraulic properties, the hydrostratigraphy in the numerical model was discretized into five layers, with 1,555 cells in each one, making a total of 7,775 cells. The cells in the model are represented by squares of $1 \times 1 \mathrm{~km}$ or $0.5 \times 05 \mathrm{~km}$, aligned with the Universal Transverse Mercator (UTM) grid. Each cell thickness varies according to the hydrostratigraphic units and values that were assigned in accordance with borehole or geophysical data. Hence, the Quaternary units (lacustrine sediments, alluvium and Quaternary volcanic rocks, breccias and blocks) are included in the first two layers, and the Cretaceous and Tertiary units are incorporated in the two deepest layers. The five layers of the model are represented by: (i) an aquitard, (ii) the mixed lithology aquifer unit, (iii) the fissured volcanic aquifer unit, $(i v)$ the fissured carbonate aquifer unit, and $(v)$ the basement rock. The assigned hydraulic properties 
A

$\leftarrow$ SW $40^{\circ}$

(E) 6

A

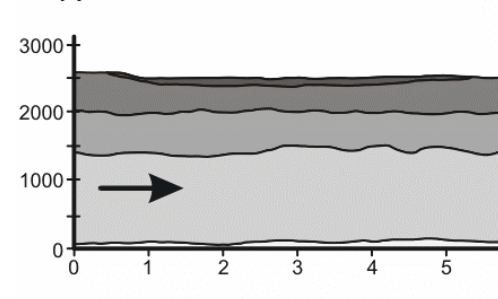

B Aguilera Borehole

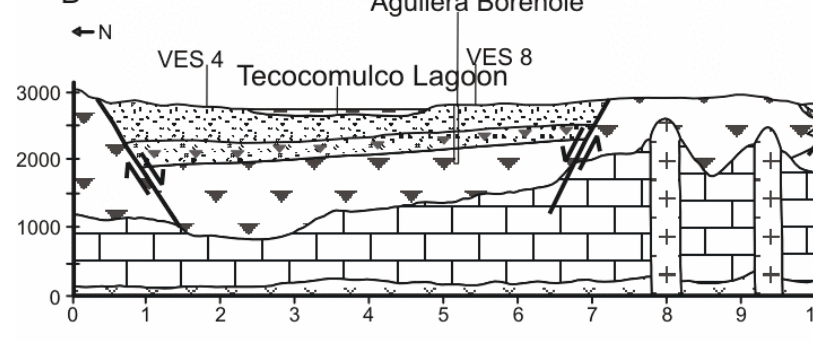

B a

\section{$A^{\prime}$}

NE $40 \rightarrow$ Acoculco Borehole

Tecocomulco sub-basin $\nrightarrow$ Acoculco sub-basin

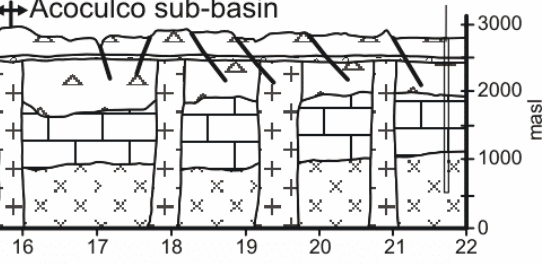

b

Tecocomulco sub-basin 4 Acoculco sub-basin

$A^{\prime}$

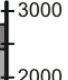
1000
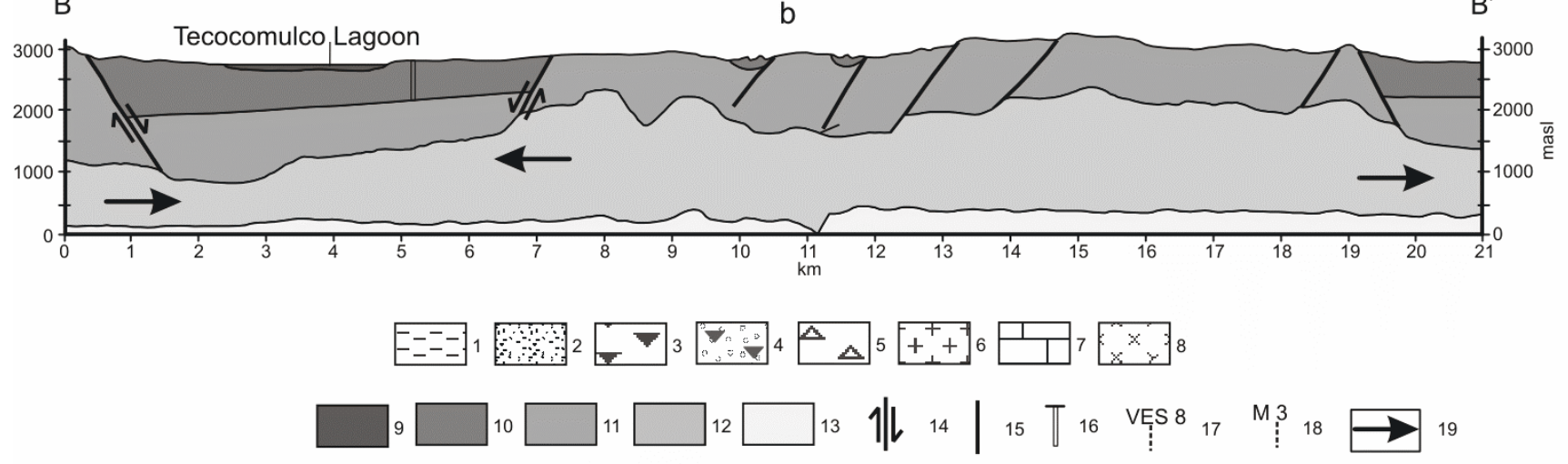

1. Lacustrine Unit (Qla), 2. Alluvial Deposits (Qal), 3. Quaternary Basaltic rocks (Qb, Qt),

4. Volcaniclastic rocks (Tma, Qal) 5. Rhyolites-Andesite rocks (Tma, Tpch, Tmovp), 6. Plutonic rocks,

7. Metamorphosed limestone (Ks), 8. Micro-granitic rock, 9. Aquitard Unit, 10. Mixed granular-fissured aquifer,

11. Fissured volcanic aquifer, 12. fissured carbonate aquifer, 13. basement complex, 14. Fault, 15. Fracture,

16. Borehole, 17. Vertical electric sounding, 18. Magnetic sounding, 19. Groundwater flow direction

For location, see figure 1

Fig. (4). Two geological cross sections based on borehole lithology, surface geology and geophysical data (location in Fig. 1). The sections show (a) the regional distribution and thickness of the geologic units, and (b) the aquifer units and the general direction of groundwater flow in the horizontal plain of the Tecocomulco region.

for layers 4 and 5 were based on values reported for the corresponding lithology in several studies carried out in this area $[14,15,24]$, as well as general from values reported in the literature $[25,26]$.

\section{Recharge and Initial Conditions}

In the study area there are 11 boreholes and 90 dug wells. The boreholes are located on the plain and their depth varies from between 80 and $150 \mathrm{~m}$. As already mentioned, groundwater is extracted from the upper part of the aquifer. The mean depth of the dug wells is about $11 \mathrm{~m}$, they are located on the plain, and each one extracts about $0.002 \mathrm{~m}^{3} \mathrm{~s}^{-1}$ of groundwater. Mean sea level was used as a reference for records of water level elevation from 1998 to 2000; data show that the depth of the potentiometric surface varies from $4 \mathrm{~m}$ in the eastern portion, to $29 \mathrm{~m}$, in the western and south-western 
Table 1. Values of Hydraulic Conductivity and Storage Coefficient for the Layers of the Model

\begin{tabular}{|c|c|c|}
\hline Strata & K & S \\
\hline \hline Recent clastic materials & Sands $2.6 \times 10^{-3}-4.3 \times 10^{-4} \mathrm{~m} / \mathrm{s}$ & $10^{-3}$ \\
\hline Recent clastic materials & Calys $3 \times 10^{-8} \mathrm{~m} / \mathrm{s}$ & $10^{-2}$ \\
\hline Pyroclastic materials & $2 \times 10^{-6} \mathrm{~m} / \mathrm{s}$ & $10^{-4}$ \\
\hline Tertiary volcanic rocks & $1 \times 10^{-3}-10^{-4} \mathrm{~m} / \mathrm{s}$ & $10^{-3.5}$ \\
\hline Meta-Limestone & $1 \times 10^{-5} \mathrm{~m} / \mathrm{s}$ & $10^{-4}$ \\
\hline
\end{tabular}

Table 2. (a, b) Values of Increased Surface Runoff and Decreased Infiltration in the Tecocomulco Sub-Basin

\begin{tabular}{|l|c|}
\hline \multicolumn{1}{|c|}{ Sub-Basin in Natural Conditions } & (a) \\
\hline \hline Surface of sub-basin $\left(\mathrm{km}^{2}\right)$ & 570 \\
\hline Mean annual precipitation $(\mathrm{mm})$ & 780 \\
\hline Mean annual evapotranspiration $(\mathrm{mm})$ & 590 \\
\hline Annual rainfall $\left(\mathrm{m}^{3}\right)$ & 444600000 \\
\hline Annual evapotranspiration $\left(\mathrm{m}^{3}\right)$ & 319200000 \\
\hline Surface runoff $\left(\mathrm{m}^{3}\right)$ & 48137596 \\
\hline Infiltration $\left(\mathrm{m}^{3}\right)$ & 77262404 \\
\hline \multicolumn{1}{|c|}{ Sub-Basin with Alteration of Vegetation } & (b) \\
\hline \hline Covering Conditions & 444600000 \\
\hline Annual rainfall $\left(\mathrm{m}^{3}\right)$ & 319200000 \\
\hline Surface runoff $\left(\mathrm{m}^{3}\right)$ & 69442064 \\
\hline Infiltration $\left(\mathrm{m}^{3}\right)$ & 55957936 \\
\hline
\end{tabular}

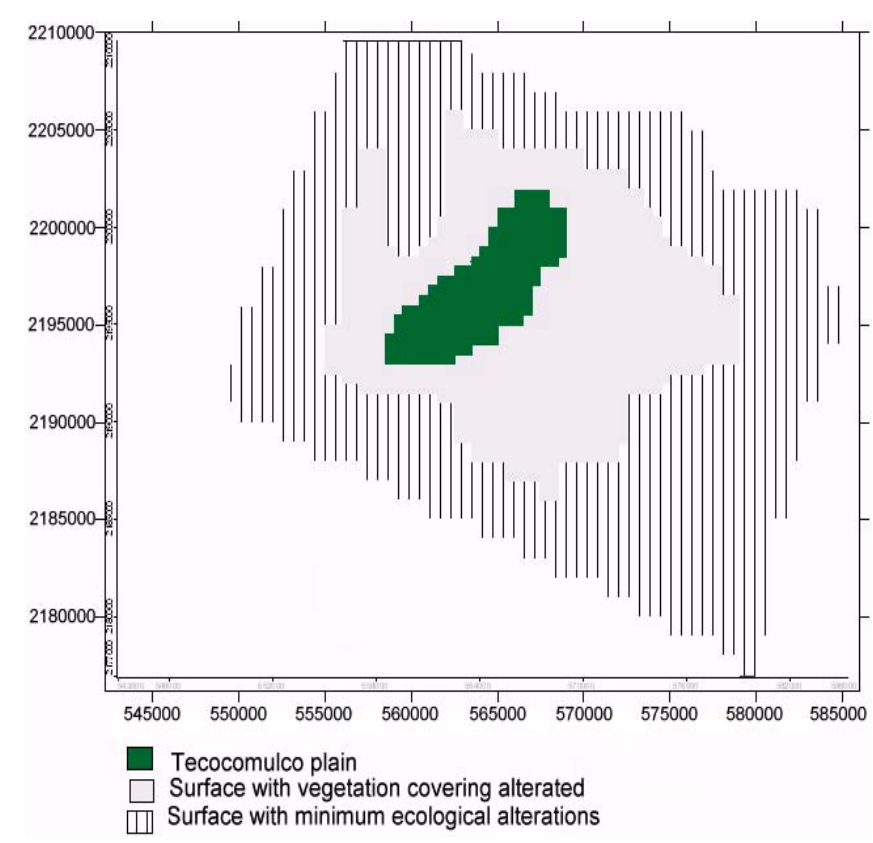

Fig. (5). Surface with soil loss and increased surface runoff due to anthropogenic ecological alterations in the study area.
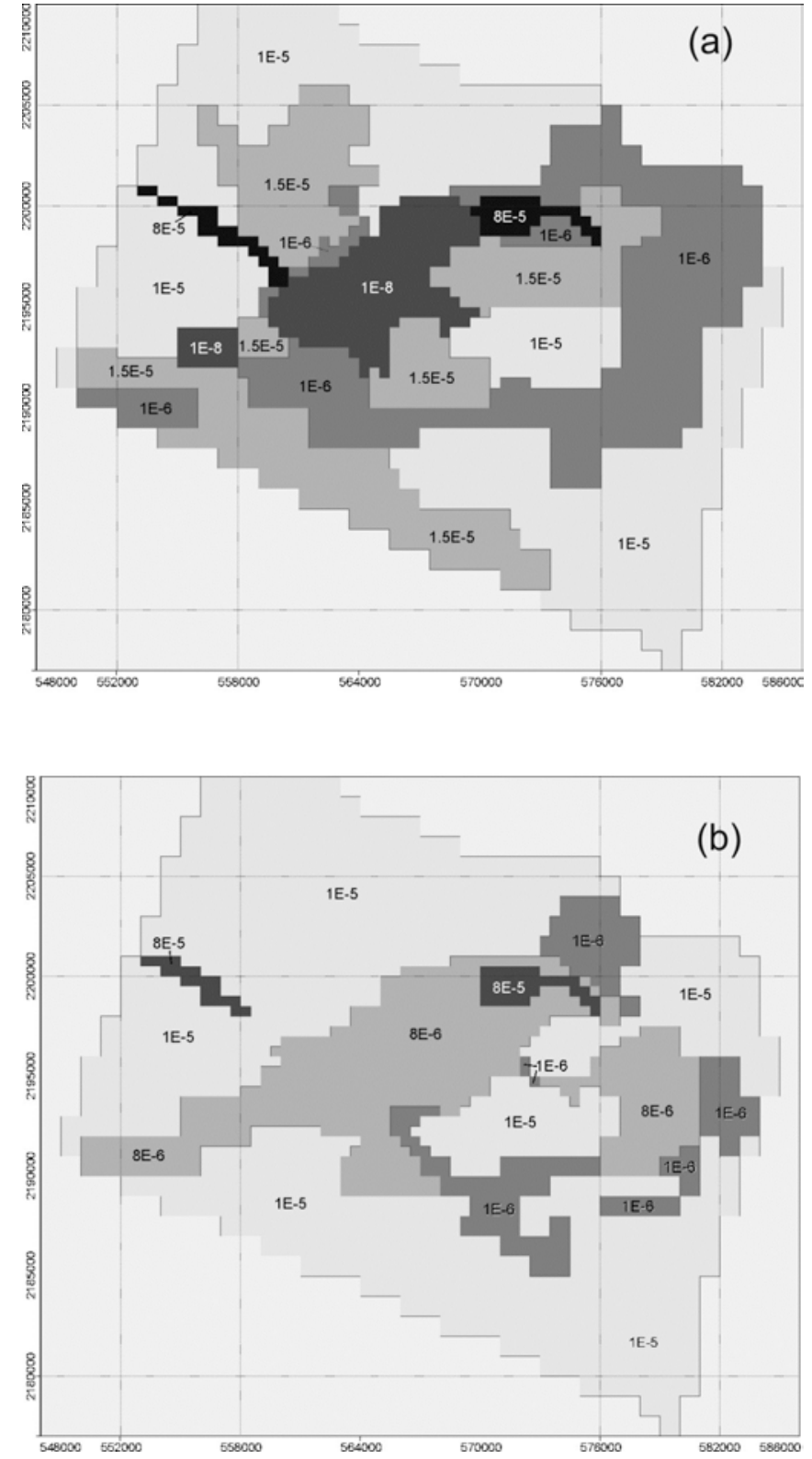

Fig. (6). Distribution and variation of values of hydraulic conductivity $(\mathrm{K})$ used for model transient flow simulation. Values of $\mathrm{K}$ are in $\mathrm{m} \mathrm{s}^{-1}$, (a) for layer I; (b) for layer II.

portions of the plain, respectively. A general decline in the water level has been identified, at an average of $0.80 \mathrm{~m} / \mathrm{year}$, with the lowest value of $0.30 \mathrm{~m} /$ year recorded at the beginning of the dry season. From 1988 to 2000, observed static water level in boreholes and dug-wells was about 0.16 $\mathrm{m} /$ year $^{-1}$. In the middle of the plain a hydraulic gradient of 0.004 was identified, measured from the periphery towards the plain centre. However, at a regional level (between Tecocomulco and Apan-Sahagún sub-basins) the water level data show that the hydraulic gradient is 0.009 .

The initial conditions of the model for the period 1980 to 2000 are based on the observed static water level in four boreholes, with its value in other sites of the study area being inferred using kriging interpolation procedures. The model was calibrated for the period 1980-2000, and thus the model may be useful for 20 year predictions. The calculated varia- 
tion of the hydraulic gradient over time (1980-2000) was compared with field data (Fig. 7a, b). The withdrawal and water level values for the year 2000 correspond to the final conditions of the calibration stage and these were considered as the initial conditions of the model for the 2000, 2010 and 2020 prediction periods.

As a part of boundary conditions, an equal water level elevation was established at the boundary of the model for each numerically simulated time. In this way, general constant heads at the borders and lateral flows to the neighbouring basins were used as boundary conditions. Both values were different either in the vertical or in the horizontal directions for each layer. A river type condition was used for the lagoon zone. After the parameter calibration, the response of the model under different $(i)$ recharge conditions, (ii) $\mathrm{K}$ and $\mathrm{S}$ values, and (iii) lateral input and outputs, was obtained. The calibration was carried out by assigning values to each layer in accordance with pumping test results and lithological conditions. Fig. (8a) shows the water level surface obtained by calibration procedures. The general procedure included the division of the simulated period in twenty oneyear time intervals; each interval was further subdivided into 10 time steps. The water level elevations obtained show groundwater flow towards the plain centre, and from there towards the south and southwest, as well as an outflow towards the north-west and east.

\section{Calibration Analysis}

Model calibration is an important step in devising an acceptable set of numerical characteristics that represent observed hydrogeological behaviour of the prototype. One procedure of calibration is based on the comparison between simulated and observed water level elevation values. The maximum obtained value of error (normalized RMS) was $3.4 \%$ obtained for calibration by comparing field to calculated values. Based on different groundwater withdrawal rates, a simulation was carried out for a five-year period in dynamic equilibrium; $\mathrm{K}$ and $\mathrm{S}$ values were adjusted for each layer, values that in turn adjusted horizontal and vertical flows. The final $\mathrm{K}$ values obtained were between $10^{-4} \mathrm{~m} \mathrm{~s}^{-1}$ and $10^{-8} \mathrm{~m} \mathrm{~s}^{-1}$, while the storage coefficient had values between $10^{-3}$ and $10^{-5}$ (Fig. 6a, b).

\section{RESULTS AND DISCUSSION}

\section{Simulation of Unsteady State}

Once the required hydraulic parameters have been calibrated for the model, its response under several withdrawal conditions was estimated. The model was calibrated for a 20year period (1980 to 2000), and a second 20-year period was simulated for prediction purposes (2000 to 2020). Each computation period was divided into several time steps, according to available information. By simulating two withdrawal alternatives, the response of the hydrological system was assessed. Alternative I considered a constant groundwater withdrawal rate $\left(0.447 \mathrm{~m}^{3} \mathrm{~s}^{-1}\right)$ from 2004 to 2020 . Alternative II, considered that in the period 2004-2020, the water withdrawal increased by $0.4 \mathrm{~m}^{3} \mathrm{~s}^{-1}$ (i.e., from 0.447 to 0.847 $\mathrm{m}^{3} \mathrm{~s}^{-1}$ ), and that the original withdrawal increased by $0.1 \mathrm{~m}^{3}$ $\mathrm{s}^{-1}$ over each three year interval. This was achieved by locating theoretical boreholes, in order to increase withdrawal, at the periphery of the plain, each extracting $0.050 \mathrm{~m}^{3} \mathrm{~s}^{-1}$. This alternative II considered two variants:

a) new boreholes would be drilled to the south of the lagoon, at Tultengo-Cocinillas site.

b) new boreholes would be drilled to the west of the lagoon, near the town of Sarabia.

Fig. (8a-f) show the evolution of the water-table elevation inside the Tecocomulco plain, which is the site where groundwater withdrawal is taking place, and hence where the water level is subject to important changes.

Alternative I, Fig. (8a) shows that the water-table elevation is located at $2,514 \mathrm{~m}$ a.s.l. This configuration is the result of the calibration in steady-state conditions.

The equipotential lines for a 20 -year forecast, with a withdrawal of $0.457 \mathrm{~m}^{3} \mathrm{~s}^{-1}$ (Fig. 8b), indicate that there is groundwater flow from the periphery towards the plain centre, and from there to the outside of the Tecocomulco subbasin: to Sahagún in the west, to Apan in the southeast, and to Tulancingo and Chignahuapan in the east (Fig. 9). The drawdown due to borehole withdrawal is located towards the towns of Sarabia, Tultengo, and Cocinillas.

The natural hydraulic gradient has a value of 0.002 , and 0.007 in the middle of these towns due to withdrawal. This human activity has also produced a visible effect by reducing the lagoon surface. These calculations were made for the period 2000 to 2020 .
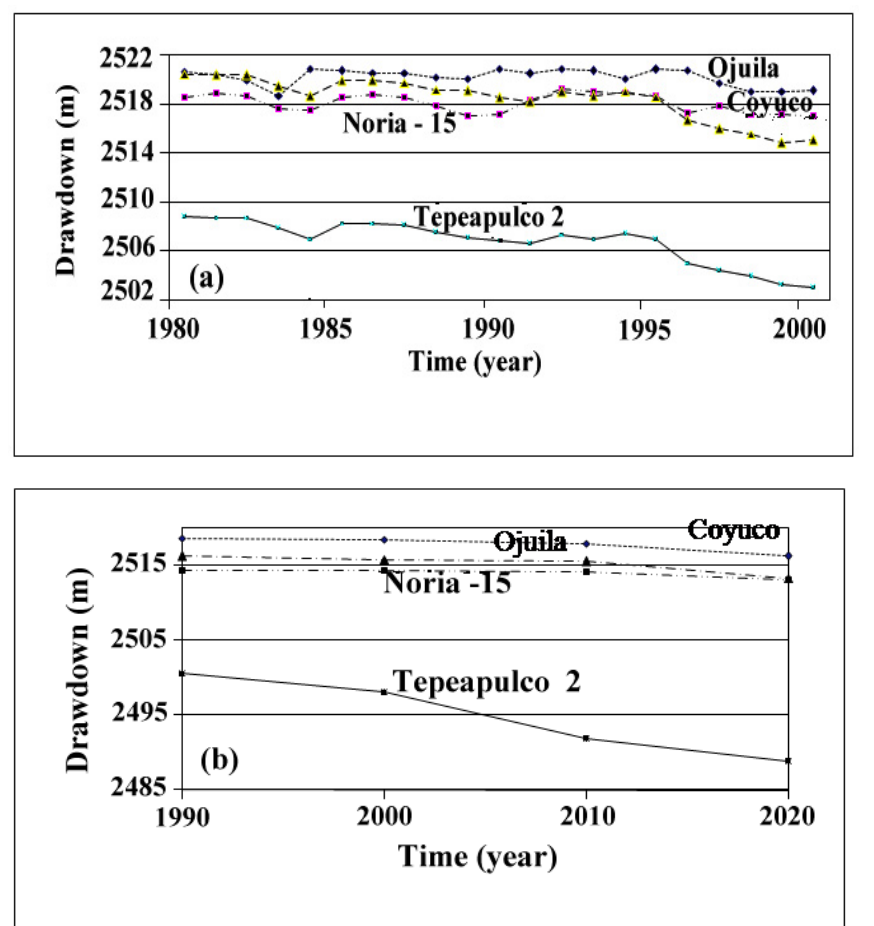

Fig. (7). Hydraulic gradient evolution (a) from 1980- 2000 in boreholes and dug-wells. (b) simulated evolution of the hydraulic gradient of Tecocomulco region for prediction periods. 

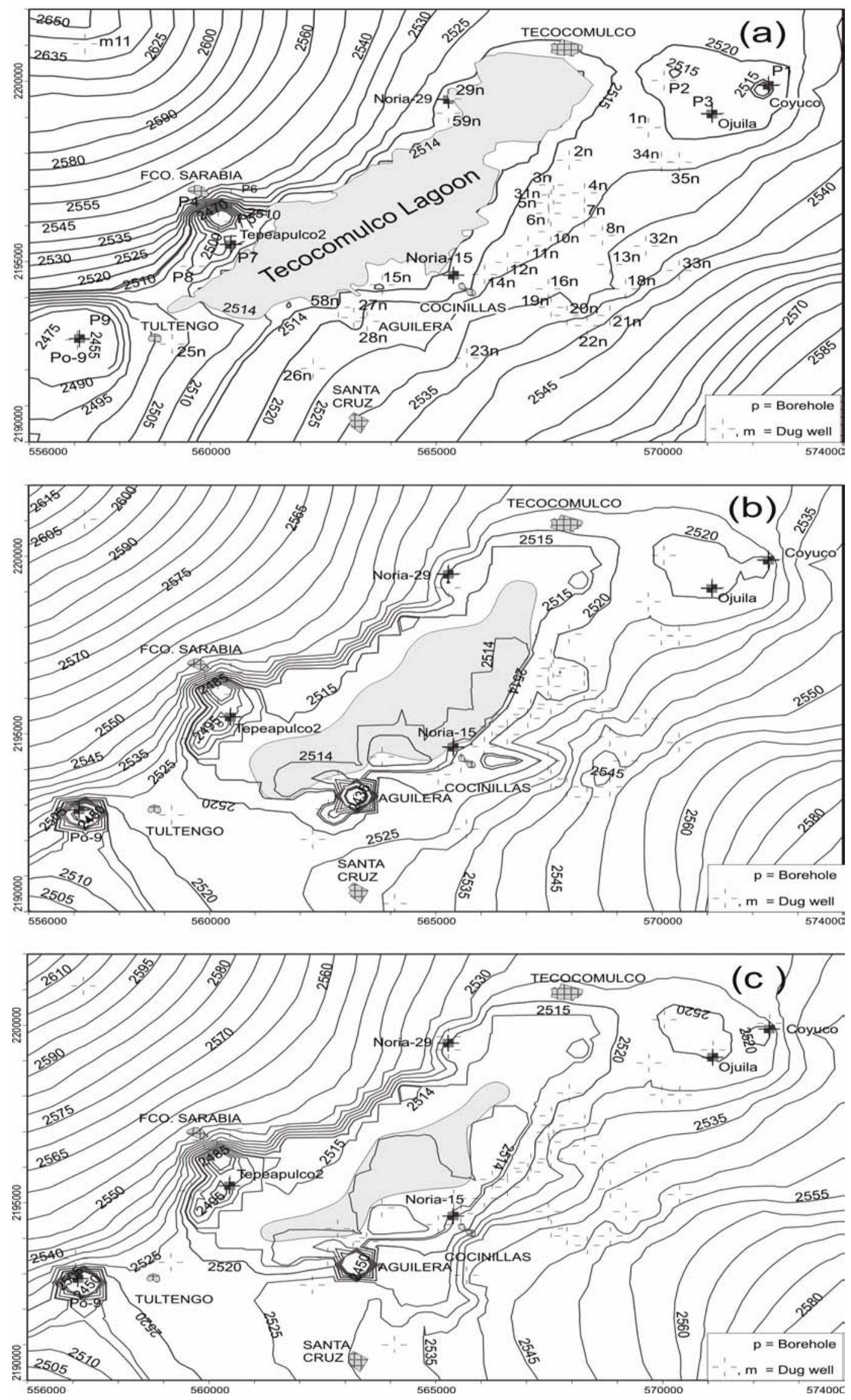

Fig. (8a-c). Simulation results from the different scenarios, note the change in size of the lagoon (shaded) with withdrawal time: (a) equipotential lines resulting of calibration (steady state conditions); (b) water-table contours for the first alternative under transient state conditions; (c) water-table contours in the first alternative for 20 years of forecast. 
Fig. (8c) shows the equipotential distribution for 2020 according to alternative I. The places affected by an important drawdown are the same as those from Fig. (8b), except that in this case the decrease of the water level and the surface containing the depression itself is larger. In the town of Sarabia, withdrawal has given rise to a drawdown-cone of 40 $\mathrm{m}$ below the plain level, while in the Cocinillas zone, at the other side of the Tecocomulco lagoon, the drawdown is $2 \mathrm{~m}$.

The present withdrawal has given rise to a groundwater divide between the towns of Sarabia and Tultengo. Similarly, water withdrawal in the SW of the plain induces a displacement of horizontal flow from the south-central part of the sub-basin towards the Sarabia zone. The equipotential 2,514 $\mathrm{m}$ a.s.l. (Fig. 8c), resulting after 20 years of withdrawal shows an increase in its water surface as compared to that from Fig. (8b). This confirms that the terrain occupied by the lagoon has been reduced considerably, and it is becoming a shallow water body where a depth of $1.5 \mathrm{~m}$, or less, is often observed. To define the withdrawal effect in the lagoon, it is necessary to indicate that its bed is at height of $2,512.7 \mathrm{~m}$ a.s.l., and its water-surface is located at 2,514.8 m. Hence, the maximum depth is $2 \mathrm{~m}$, and is located almost in the central portion of the water body.

Alternative II, variant (a). In this scenario, the water withdrawal is increased by $0.1 \mathrm{~m}^{3} \mathrm{~s}^{-} 1$ in each of the threeyear computed intervals where the corresponding boreholes are placed at the intersect of Cocinillas-Tultengo. Fig. (8d) shows the elevation of the water-table corresponding to a forecast of 15 years. The withdrawal rate has been increased by $0.400 \mathrm{~m}^{3} \mathrm{~s}^{-1}$, with respect to the rate at the beginning of the prediction $\left(0.447 \mathrm{~m}^{3} \mathrm{~s}^{-1}\right)$, obtaining $0.847 \mathrm{~m}^{3} \mathrm{~s}^{-1}$. Despite the double withdrawal increase, the configuration of the equipotential is very similar to those obtained in alternative I, except that at the sites of Cocinillas and Tultengo, there are broad zones affected, mainly those where the dug-wells are located. The equipotential line 2,514 $\mathrm{m}$ a.s.l. limits the zone of influence by dug-wells, while in Sarabia, there is an important drawdown cone. Nevertheless, there is a groundwater flow from the NW towards Cocinillas and Tultengo. Fig. (8d) shows that the lagoon has lost a large amount of water surface, and is becoming a shallow water body. Fig. (8e) shows the withdrawal effect. The elevation of the watertable $(2,514 \mathrm{~m}$ a.s.l.) now includes an even greater surface than that observed (Fig. 8d), while the main dry zone is to the SE and towards the NW. This represents the influence of water withdrawal at Cocinillas.

Variant (b) from alternative II analyzes the withdrawal effect on the lagoon when the new boreholes are drilled to the west of the lagoon, near the town of Sarabia. Fig. (8f) indicates the water-table elevation distribution for the year 2020.

This configuration indicates that independently of the location of the new boreholes, the increase in groundwater withdrawal negatively affects the existence of the lagoon. One difference between scenarios II (a) and II (b) is that 20 years after having increased the withdrawal rate, in the second scenario, the lagoon surface is larger than in the first one. Nevertheless, in the end it becomes a shallow water body, although more time is required for this change to be observed. Withdrawal in the Sarabia zone produces a drawdown reaching the Tultengo zone and a change in groundwater flow pattern, moving to the west instead of towards the south.

This modelling exercise confirms the previous interpretation of the existence of a local and an intermediate groundwater flow system $[5,10]$. It is inferred that under natural conditions, recharge occurs in the high parts of the relief, while the discharge appears in the piedmont and in the lowest sites of the topography. Modelling procedures allowed observed drawdown levels and initial conditions to be inferred from where the response to withdrawal and the actual effect of desiccation of the lagoon was reproduced independently of the location of boreholes. This, however, is time dependant. In the study area, recharge was reproduced to occur in the mountain ranges that surround the plain located 3 and $10 \mathrm{~km}$ away. According to the flow path reproduced by the model, this recharge is observed to constitute intermediate and regional flows that discharge in neighbouring areas, outside this sub-basin. Discharge of local groundwater flow systems takes place in the plain, ending in the Tecocomulco lagoon.

\section{CONCLUSIONS}

Modelling assisted in the verification of effects caused by current groundwater withdrawal: time dependant desiccation of the lagoon was reproduced independently of the location of boreholes. It also helped in interpreting the existence of local and intermediate groundwater flow systems $[5,10]$ and regional flows that discharge in neighbouring areas, outside this sub-basin. The discharge zones of the local groundwater flow systems are located around the plain they flow into, and also in the Tecocomulco lagoon itself. The behaviour of the potentiometric surface as simulated with the model confirms the presence of an upward vertical groundwater flow that is producing a discharge in the Tecocomulco plain.

Present water supply is based on the local groundwater flow system; the intermediate and regional flow that travels outside the sub-basin constitutes inflows from neighbouring areas. It has been found that the evolution of the size and depth of the lagoon is affected by different schemes; in historical times the natural sediment deposition effect was very slow, but this process is accelerated when the population strongly alters the environment, and this alteration causes soil erosion. The lagoon has been further affected by the increasing withdrawal of groundwater over time.

Locally, the infiltration/runoff ratio is being affected by a significant reduction in vegetation cover in the study area. The large soil loss and the increase in surface runoff are evidence of this outcome [23]. Evidence of this process appears to be supported by the $35 \%$ decrease in the local recharge volume as computed in this study. The findings suggest the need to design a management approach that in addition to incorporating the physical characteristics of the media, also includes social and economical aspects of any future development of the area. Such management should involve the preservation of the lagoon to become a natural protected zone preserving its wetland characteristics. 

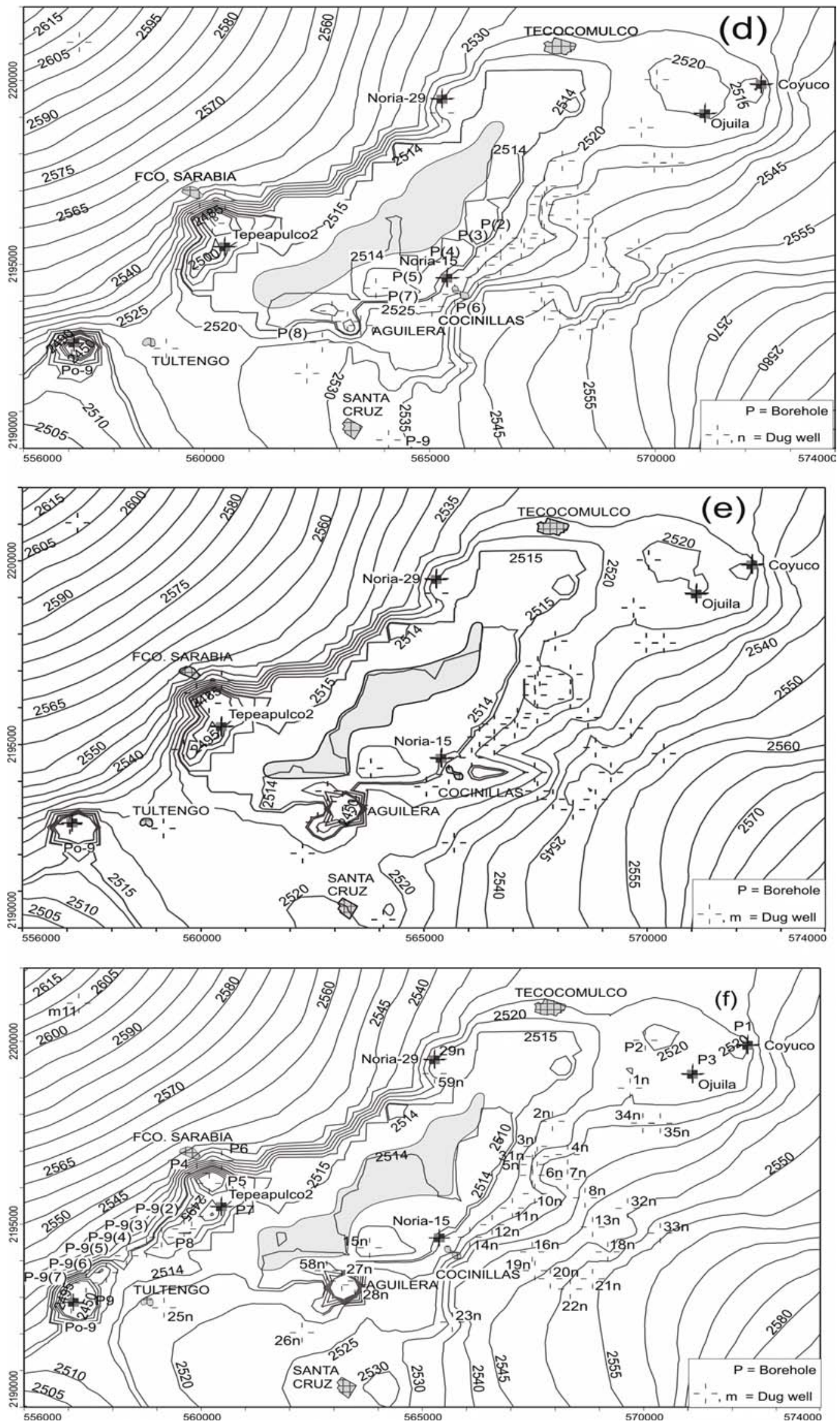

Fig. (8d-f). Simulation results from the different scenarios, note the change in size of the lagoon (shaded) with withdrawal time (d) equipotential lines in alternative 2a after 12 years, (e) equipotential lines in alternative $2 \mathrm{a}$ after 20 years of forecast; and (f) water-table elevation lines for alternative $2 b$. 

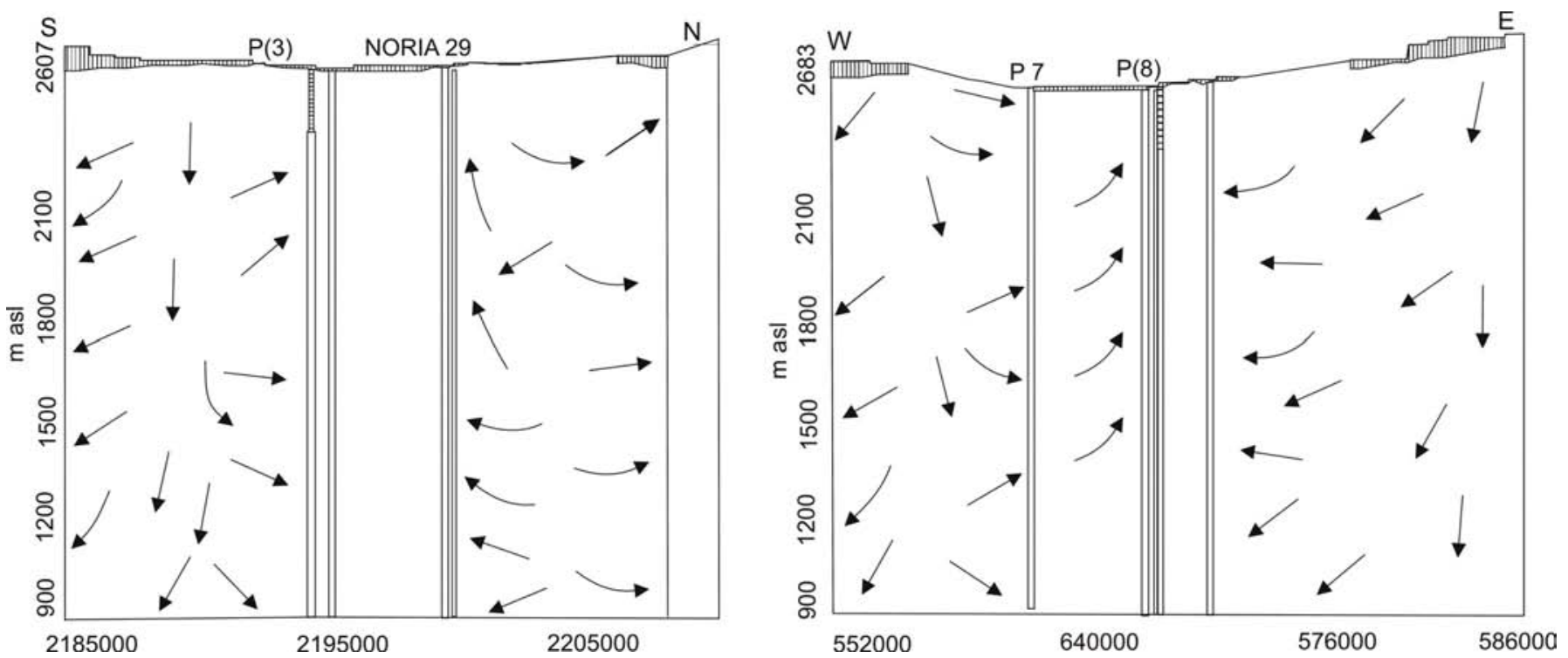

Fig. (9). Simulated flow lines in the two vertical cross sections, in the five discretized layers (location in Fig. 1). Upward flow at the centre of the plain, downward flow in the periphery towards the neighbouring areas (for location see Fig. 1).

The Tecocomulco lagoon is the last remaining prehispanic body of water in the Mexico Basin, but ecological transformations brought about by the local population endanger its existence. The observed gradual disappearance of vegetation cover represents the most urgent problem to be solved, as this cover provides support to related ecosystems, such that groundwater provides the main support to vegetation, and therefore this brings threats of:

- The disappearance of flora and fauna in the sub-basin. The Tecocomulco lagoon constitutes the last ecological site where 36 species of aquatic plants that have inhabited the lakes of the centre of Mexico survive. This lagoon also constitutes the habitat of several species of vertebrates endemic to Mexico, and is a place of rest and hibernation for many thousands of migratory and terrestrial birds that arrive annually from southern Canada and the northern United States $[2,4]$.

- $\quad$ Soil is being uncovered and exposed to erosion processes. The calculated magnitude of the loss of soil [23] is of almost 40,000 tons per year, of which up to $40 \%$ is deposited in the lagoon.

- The hydrological system where the lagoon is the main element may disappear. It presents physical alterations as erosion, deposition of soils into the lagoon, and runoff increase, and its recharge potential for regional groundwater flow systems is also reduced. It is important, therefore, to carry out reforestation and reorganize suitable programmes of soil usage to stabilize the environmental alteration of this sub-basin and to avoid an ecological disaster.

\section{ACKNOWLEDGEMENTS}

This study was conducted with financial grant IN-107996 from the Dirección General de Asuntos del Personal Académico (DGAPA) of the Universidad Nacional
Autonóma de México (UNAM). The Institute of Geology supported field activities. Gerardo Zenteno assisted in computation tasks.

\section{REFERENCES}

[1] Ramírez JF. Description on the flooding and building of Mexico City. SEP-INAH : México 1976. (in Spanish)

[2] Jiménez E, Juárez LC. The Tecocomulco lagoon an important zone for the Mexican birds conservation. Teocalli: México 2000; 2: 1-9. (in Spanish).

[3] Serra-Puche MC. The lacustrine resources at the Mexico basin during formative. Inst de Antropol Mexico, 1988. (in Spanish).

[4] Lot-Helguera A, Novelo E. The Tecocomulco Lagoon, Hidalgo. Guide book of botanic excursions in Mexico. Botanic Soc: Mexico 1978; p. 19 (in Spanish).

[5] Huizar-Alvarez R, Mitre-Salazar LM, Campos-Enríquez O, et al. Hydrogeologic evaluation of Sub-basin of Tecocomulco, States of Hidalgo, Tlaxcala y Puebla. Rev Mexicana de Ciencias Geológicas 2001; 18 (1): 55-73. (in Spanish).

[6] Marín-Córdova S, Torres-Ruata C. Hydrogeologic map of the mexican republic scale 1:4 000 00. National Mexico Atlas. (Naturaleza. Spainish IV 6.3). Inst. Geogr. Universidad Nacional Autónoma de México: Mexico 1990 (in Spanish).

[7] Alatriste-Vilchis DR. Determination of the sub-surface structure of the Tecocomulco sub-basin, through geophysical techniques, Universidad Nacional Autónoma de México, Mexico 1999. (in Spanish).

[8] García-Palomo A, Macias JL, Tolson-Jones G, Valdéz G, MoraChaparro JC. Volcanic stratigraphy and geological evolution of the Apan region, east-central of the Transmexican Volcanic Belt. Geofísica Int 2002; 41 (2); 133-50.

[9] Campos-Enriquez JO, Alatristre-Vilchis DR, Huizar-Alvarez R, Marines-Campos R, Alatorre-Zamora MA. Subsurface structure of the Tecocomulco sub-basin (northeastern Mexico basin), and its relationship to regional tectonics. Geofísica Int 2003; 42(1): 3-24.

[10] Huizar-Alvarez R, Kobr M, Mitre-Salazar LM, Campos-Enríquez $\mathrm{O}$, Alatriste-Vilchis DR. Hydrogeological research in the Sub-basin of Tecocomulco, State of Hgo: Proceeding $4^{\circ}$ Conf. ALHSUD; Montevideo, Uruguay 1998; 3: 1315-22. (in Spanish).

[11] Ledezma-Guerrero O. Geological map 14Q-h(3) and explanation. States of Hidalgo, México y Tlaxcala, Serie de 1:100 000, Inst. Geología. Universidad Nacional Autónoma de México: Mexico, 1987. (in Spanish).

[12] De la Cruz-Martínez V, Castillo-Hernánez D. Geologic study of the Acoculco Caldera geothermal zone. Comisión Federal de Electricidad, México 1986. (in Spanish). 
[13] Kobr M. Water flow control in monitoring boreholes: Proceeding $4^{\circ}$ Conf. ALHSUD. Uruguay 1988; 3: 1161-73. (in Spanish).

[14] López-Hernández A, Castillo-Hernández D. Exploratory Drilling at Acoculco, Puebla, Mexico: A hydrothermal system with only nonthermal manifestations. Geoter Resou Coun Trans 1997; 21: 429-33.

[15] SARH. Geohydrologic study of the Apizaco-Soltepec area, Tlaxcala: México; 1981. (in Spanish).

[16] Huizar-Alvarez R, Hernández-García G, Kobr M. Flow systems identification in the Tecocomulco sub basin, Mexico: Proceeding XXXIII Conf. AIH \& $7^{\circ}$ Conf. ALSHSUD; 2004; Zacatecas, México.PdflT9-45.

[17] Thiessen AH. Precipitations averages for large areas: Monthly Weather Rev Juillet 1911; pp. 108.

[18] Blaney HF, Criddle WD. Determining consumptive use irrigation water requirements. Department of Agriculture. Washington, D.C. USA: Tech Bull 1962; 1275.
[19] Turc L. Estimation of irrigation water requirement, potential evapotranspiration: A simple climatic formula evolved up to date. Ann Agron 1961; 12:13-14

[20] Mc Cuen W. Hydrologic analysis and design. $2^{\text {nd }}$ ed. Prentice Hall: NJ. USA; 1998.

[21] Maidment RD, Handbook of Hydrology. Mc Graw-Hill, Inc.; 1993.

[22] McDonald MG, Harbaugh AW. A modular three-dimensional finite difference groundwater flow model. USGS Techniques of Water Resources Investigation Report 1988; book 6, Ch. A1.

[23] Ruiz-González JE. Erosion assessment in the Tecocomulco subbasin, Hidalgo, Puebla and Tlaxcala States, Universidad Nacional Autónoma de México; 2000. (in Spanish).

[24] Huizar-Alvarez R. Hydrogeologic map of the Sub-basin of de las Avenidas river, Pachuca, Hgo Inv Geográficas Universidad Nacional Autónoma de México 1993; 27: 95-131.

[25] Domenico AP, Schwartz WF. Physical and Chemical Hydrogeology. $2^{\text {nd }}$ ed. John Wiley \& Sons Inc, NY: USA; 1998.

[26] Batu V. Aquifer hydraulics (A comprehensive guide to hydrogeologic data analysis). John Wiley \& Sons Inc. NY: USA; 1998.

(C) Huizar-Alvarez et al.; Licensee Bentham Open.

This is an open access article licensed under the terms of the Creative Commons Attribution Non-Commercial License (http://creativecommons.org/licenses/by$\mathrm{nc} / 3.0 /$ ) which permits unrestricted, non-commercial use, distribution and reproduction in any medium, provided the work is properly cited. 